\title{
Workaholism and family interaction among nurses
}

\author{
Adição ao trabalho e interação familiar em enfermeiros
}

Elisabete Maria das Neves Borges (https://orcid.org/0000-0002-6478-1008) ${ }^{1}$

Carlos Alberto da Cruz Sequeira (https://orcid.org/0000-0002-5620-3478) ${ }^{1}$

Cristina Maria Leite Queirós (https://orcid.org/0000-0002-8045-5317) ${ }^{2}$

Maria Pilar Mosteiro-Díaz (https://orcid.org/0000-0002-3375-9334) ${ }^{3}$
${ }^{1}$ Escola Superior de Enfermagem do Porto, Centro de Investigação em Tecnologias e Serviços de Saúde. Rua Dr. António Bernardino de Almeida. 4200-072 Porto, Portugal. elisabete@esenf.pt ${ }^{2}$ Faculdade de Psicologia e de Ciências da Educação da Universidade do Porto. Porto, Portugal.

${ }^{3}$ Facultade de Medicina e Ciências da Saúde, Universidad de Oviedo. Asturias, Espanha.
Abstract This study aims to identify the prevalence of workaholism and work-family interaction, their relationship and their variation according sociodemographic and occupational characteristics among nurses. A quantitative, descriptive, correlational and transversal study was conducted with a sample of 839 Portuguese nurses. Regarding workaholism, 27\% of workaholic nurses were identified, scoring a higher mean value for excessive work. For work-family interaction, the dimensions showing the highest mean values were the negative work-family interaction and the positive family-work interaction. The variables identified as significant predictors of workaholism were the work-family interaction (39\%), occupational variables $(10.6 \%)$ and sociodemographic variables (1.2\%). Among the occupational and professional variables, the women, age equal or less than 37 years and perception of stressful work, were highlighted. The confirmation of workaholism in nurses, as well as its predictive variables are significantly important for professionals and organizations to better understand the impact of this phenomenon, particularly in mental health and to encourage the development of programmes aiming to promote health at the workplace.

Key words Workaholism, Work addiction, Family conflict, Nursing, Mental health
Resumo $O$ objetivo deste estudo foi identificar a prevalência da adição ao trabalho, os níveis de interação trabalho-família e a relação destes com características sociodemográficas e laborais em enfermeiros. Estudo quantitativo, descritivo, correcional e transversal numa amostra de 839 enfermeiros de Portugal continental. Relativamente à adição ao trabalho, identificaram-se 27,1\% de enfermeiros adictos, com valor médio superior no trabalho excessivo. No que respeita à interação trabalho-família, as dimensões com médias superiores foram a interação negativa trabalho-familia e a interação positiva família-trabalho. As variáveis identificadas como preditores significativos da adição ao trabalho foram a interação trabalhofamília (39\%), as variáveis laborais (10,6\%) e as sociodemográficas $(1,2 \%)$. Das variáveis laborais e profissionais salienta-se o sexo feminino, idade igual ou inferior a 37 anos e a perceção de trabalho stressante. A confirmação deste fenómeno em enfermeiros, assim como, das variáveis que o podem potenciar, possibilita ao profissional e às organizações, uma maior consciencialização dos seus impactos, nomeadamente na saúde mental incentivando o desenvolvimento de programas que visem a promoção de saúde no local de trabalho.

Palavras-chave Dependência, Trabalho, Conflito familiar, Enfermagem, Saúde mental 


\section{Introduction}

Work is a significant part of people's life. Many organizations have strived to understand the impact of work in the quality of life of workers and their families, organizations, and the quality and safety of care provided. In 2017, the International Labour Organization presented the Safety and Health at Work objective as part of the Decent Work and the 2030 agenda for sustainable development ${ }^{1}$.

Recognizing the importance of work-life balance, the Eurofound identifies intensity, regularity, flexible work schedules, support from the administration and colleagues, as cardinal factors for achieving this balance ${ }^{2}$. In 2019, this organization also called attention to the new upcoming challenges concerning increasing ageing of the population and prolonged active life at work worldwide ${ }^{3}$. Similarly, the development and the increasing innovation in eliciting digital technologies have led to labour changes increasing connectedness among workers ${ }^{4}$. All these related factors, such as work overload, work pressure and competitiveness, role conflicts and the unpredictability of events (like the current outbreak of COVID-19 pandemic), characterize many of the work environments, with significant impact on family relationships ${ }^{5-7}$.

Among many other professionals, nurses are often exposed to harmful work environments, and these professionals experience particular situations related to the nature of a highly demanding and stressful profession, both at physical and emotional levels, affecting health, family interaction and quality of care delivery ${ }^{8-10}$.

The phenomenon of workaholism has also been found in nurses, with high risks for their psychological and physical health ${ }^{11-13}$. Workaholism is characterized by obsessive behaviour ${ }^{14}$ and literature has put forward some theoretical models aiming to its conceptualization, namely, the Affection-cognition-behaviour ${ }^{15}$, the Role Conflict $^{16}$ and the Personality and Inducements ${ }^{17}$. Affection-cognition-behaviour is associated with the dimensions of affection, cognition and behaviour, and is evidenced when the worker enjoys his/her work, experiences some type of anxiety when not engaged in work and is somewhat over-committed, nevertheless, finds it satisfying. The role conflict appears as a facilitator, and according to its authors, workaholism is related to negative well-being and burnout. Finally, the Personality Traits and Inducements model, advocates that workaholism is a result of the interac- tion between personality traits, and personal and organizational inducements.

Moreover, some studies point out as consequences of this phenomenon, cardiovascular complications, sleep pattern disorders and increased levels of stress ${ }^{18-19}$, the burnout syndrome and secondary traumatic stress ${ }^{14,20}$, mental health problems $^{21}$ and changes in the family relationship ${ }^{22-24}$.

Early studies on the work-family relationship focused on the difficulties of interaction and the negative side of the conflict ${ }^{25}$. When addressing these multiple inhibiting factors in the management of professional and family roles, Authors called conflict to the negative interaction between work-family and family-work and identified these as related but independent constructs $^{26}$. Moreover, the positive influence of work-family and family-work stems from the contribution of positive psychology. Some examples of this influence are the development of social skills $\mathrm{s}^{27}$ and social recognition ${ }^{28}$. Furthermore, authors identified the integrative perspective of the work-family interaction as a mutual influence, either negative or positive ${ }^{29}$.

Although this latter perspective allows broader visibility, the literature has shown a greater predominance of negative relationships in the work-family interaction ${ }^{30}$, associated with the work environment, such as ambiguity and role conflict $^{31}$, burnout ${ }^{32}$, increased use of technology $^{33-34}$, job satisfaction ${ }^{35}$ and absenteeism ${ }^{36}$. However, some other factors were found to be related to the family, such as the demand for household chores and the parental role ${ }^{25,37-38}$.

Regarding nurses, the literature suggests the association between family conflict, depression and musculoskeletal disorders ${ }^{39}$, quality of sleep ${ }^{40}$, satisfaction and intention to leave ${ }^{41}$, burnout $^{30,42-43}$, quality of care delivery ${ }^{44}$, work context ${ }^{45}$ and workaholism ${ }^{46-48}$.

Thus, this study aims to identify the prevalence of workaholism and work-family interaction, their relationship and their variation according sociodemographic and occupational characteristics among nurses.

\section{Methods}

\section{Study design and Participants}

A quantitative cross-sectional and correlational study design was used. A convenience sample of Portuguese nurses with time profes- 
sional experience equal or more than one year was recruited. The Portuguese Order of Nurses supported this study by emailing a newsletter and making available a link to all registered nurses. A total of 839 nurses participated in the study, a valid sample considering the sample size of 729 nurses (100\% response rate), for a $95 \%$ confidence level, accuracy of $3.25 \%$ and expected prevalence of workaholism of $28.3 \%$. Data collection was performed between October and December 2019.

\section{Instruments}

For the data collection, a survey was developed, integrating a sociodemographic and professional questionnaire, the Dutch Work Addiction Scale ${ }^{14,49}$ (DUWAS) to assess workaholism, and the Survey Work-Home Interaction NijmeGen $^{29-30}$ (SWING) to identify work-family interactions.

The 10-item DUWAS is assessed through a 4-point Likert scale (1-never to 4-everyday) and includes two dimensions: excessive work (five items, behavioural component) and compulsive work (five items, cognitive component). According to the authors, participants with scores equal to or higher than the 75th percentile in the combination of compulsive work and excessive work or in the score of addition to work were considered work addicts. ${ }^{14}$

SWING integrates 22 items with a 4-point Likert response option ranging from 0 -never to 3-always, and four dimensions enabling to assess the work-family relationship in terms of direction (work-family and family-work) and quality of influence (negative and positive). It should be noted that the negative influence expresses the work-family conflict, according to its direction. For each dimension, high scores correspond to high levels of either positive or negative work-family interaction.

The reliability of results was assessed through the Cronbach alpha coefficient. The DUWAS scores ranged between $\alpha 0.753$ and $\alpha 0.81$, and SWING between $\alpha 0.796$ and $\alpha 0.896$ (Table 1), suggesting acceptable and good internal consistency. ${ }^{50}$ These results corroborate those found in validation studies ${ }^{14,29-30,49}$.

\section{Data analysis}

Quantitative analysis of data was performed using the program for statistical and epidemiological analysis of data (EPIDAT version 4.2) and Statistical Package for the Social Sciences (IBM-SPSS version 25.0). Absolute and relative frequencies mean and standard deviation were used for descriptive analysis, as well the Pearson Correlation Coefficient for inferential analysis, and the Stepwise method for multiple linear regression. The statistical significance level was set at $5 \%(\mathrm{p}<0.005)$.

\section{Ethical considerations}

The study was approved by the Ethics Committee of Nursing School of Porto (2019/1526) and the Council of the Portuguese Order of Nurses collaborated in disseminating the study on its web page. The nurses willing to participate could access the information on this study through a link made available, which also included informed consent. Upon acceptance, the participants were able to fill the questionnaire.

\section{Results}

From the total participants, $82 \%$ were women, $63 \%$ were married or cohabiting, $61 \%$ had children, and were aged on average 38 years $(S D=9.7)$, ranging between 21 and 61 years. As for academic qualifications, the majority had an undergraduate degree $(49 \%)$, followed by a master's degree (24\%). The average time of professional experience was 16 years $((\mathrm{SD}=9.8)$, being $58 \%$ of the sample working in hospitals and $25 \%$ in primary health care, with a permanent employment contract (89\%) and shift work (59\%). As for the geographical area, the majority of participants were located in the northern region (59\%), followed by the centre $(21 \%)$ and south $(20.4 \%)$. Concerning the perception of stress related to the professional activity, $90 \%$ of respondents considered it stressful and $61 \%$ of nurses referred to engaging in after-work leisure activities.

The results obtained for workaholism, according to the cut-off point as proposed by authors ${ }^{14}$ highlighted a prevalence of $27.1 \%$. Concerning the mean value for dimensions compulsive work and excessive work, moderate values were found, scoring lower for compulsive work and overall workaholism when compared with excessive work (Table 1).

For the work-family interaction (Table 1), weak and moderate mean values were found for the four dimensions of the scale (.93 to 1.31), with higher mean values for the negative work- family interaction and positive family-work interaction, 
Table 1. Mean, standard deviation, Cronbach Alpha, Pearson correlations between dimensions DUWAS and SWING.

\begin{tabular}{|c|c|c|c|c|c|c|c|c|c|}
\hline Variables & $\mathbf{M}$ & SD & $\begin{array}{c}\text { Cronbach } \\
\text { Alpha }\end{array}$ & 1 & 2 & 3 & 4 & 5 & 6 \\
\hline 1. Compulsive work & 2.05 & 0.56 & 0.753 & & & & & & \\
\hline 2. Excessive work & 2.67 & 0.52 & 0.628 & $0.546^{* *}$ & & & & & \\
\hline 3. Workaholism & 2.36 & 0.48 & 0.817 & $0.888^{\star *}$ & $0.870^{* *}$ & & & & \\
\hline 4. Negative work-family interaction & 1.31 & 0.58 & 0.896 & $0.475^{\star *}$ & $0.619^{* *}$ & $0.619^{* *}$ & & & \\
\hline 5. Negative family-work interaction & 0.93 & 0.63 & 0.804 & $0.149^{\star *}$ & $0.199^{* *}$ & $0.197^{\star \star}$ & $0.343^{\star *}$ & & \\
\hline 6. Positive work-family interaction & 1.09 & 0.57 & 0.799 & -0.20 & $-0.092^{\star *}$ & -0.062 & $-0.204^{* *}$ & 0.024 & \\
\hline 7. Positive family -work interaction & 1.22 & 0.67 & 0.796 & 0.060 & 0.056 & 0.066 & -0.030 & 0.040 & $0.501^{\star \star}$ \\
\hline
\end{tabular}

${ }^{* *} \mathrm{p} \leq .010$

Source: Authors elaboration.

followed by the positive work-family interaction and the negative family-work interaction.

The analysis of correlations (Table 1) showing a positive and moderate association of workaholism, compulsive work and excessive work with the negative work-family interaction, and a very weak association with the negative family-work interaction. ${ }^{51}$ Finally, the positive work-family interaction showed only a weak statistical association with excessive work. In sum, the results showed a relatively weak association of workaholism with the family-work interaction in both directions.

The Stepwise multiple linear regression was calculated to analyse the variables that best explained workaholism (Table 2). The sociodemographic (gender, age, civil status, children and academic qualification) and work (time of professional experience, local and geographical area, employment contract, shift work, perception of stressful work and leisure activities) variables were considered, as well as the dimensions of the Work-Home Interaction Scale.

Table 2 displays the variables identified as significant predictors. The data show that workaholism is explained by the relationship of the work-family interaction (39\%), occupational variables $(10.6 \%)$ and sociodemographic variables $(1.2 \%)$; the compulsive work by the relationship of work-family interaction (23.1\%), occupational variables $(7.6 \%)$ and sociodemographic variables $(1.8 \%)$; and the EW by the relationship of work-family interaction (38.8\%), occupational variables $(9.9 \%)$ and sociodemographic variables $(0.7 \%)$.

The linear regression also revealed that the best predictors for workaholism were the variables negative work-family interaction accounting for $38.3 \%$ ( $\beta=-.621)$, the perception of stressful work, scoring 7\% ( $\beta=-.246$, those who perceive their work as stressful) and gender reaching .7\% ( $\beta=-.083$, women). As for compulsive work, results showed that the variables negative work-family interaction accounted for $22.5 \%(\beta=-.487)$, the perception of stressful work scored $3.6 \%$ ( $\beta=-.197$, those who perceive their work as stressful) and age reached $1.7 \%$ ( $\beta=-.136$, the younger nurses). Finally, the higher predictive values for excessive work were found in the variables negative work-family interaction, accounting for $38.3 \%(\beta=-.621)$, the perception of stressful work, scoring $7.9 \%$ ( $\beta=-.267$, those who perceive their work as stressful) and gender, reaching $0.7 \%$ ( $\beta=-.082$, women).

Thus, work-family interaction is the best predictive variable for workaholism and its dimensio ns.

\section{Discussion}

Regarding the prevalence of workaholism among nurses, the $27.1 \%$ score found in this study was higher when compared to that identified in Italian nurses ${ }^{13}$ accounting for $21 \%$ and $13.7 \%$ in Iranian nurses ${ }^{19}$. Concerning workers in management areas, identified a prevalence of workaholism of $9.4 \%{ }^{52}$, while in medical residents ${ }^{16}$ it was $16 \%$ and $29 \%$ in a sample of Brazilian workers ${ }^{53}$.

Regarding the dimensions of workaholism, they showed a higher mean value for excessive work compared to compulsive work, in line with the results of other study ${ }^{54-55}$. However, in a study with Italian nurses ${ }^{56}$ and university academics technical and administrative personnel in Norway $^{24}$, compulsive work scored slightly higher.

Considering the work-family interaction, the negative influence expressed in the work-family 
Table 2. Multiple regression analysis (Stepwise) for workaholism using sociodemographic/professional, variables and work-family interaction's dimensions.

\begin{tabular}{|c|c|c|c|c|c|c|c|c|c|}
\hline Dimensions & Pred & ctors & $\begin{array}{c}\mathbf{R} \\
\text { Square }\end{array}$ & $\begin{array}{l}\text { R Square } \\
\text { change }\end{array}$ & $\boldsymbol{\beta}$ & $\mathbf{t}$ & $\mathbf{p}$ & $\mathbf{F}$ & $\mathbf{p}$ \\
\hline \multirow[t]{8}{*}{ Workaholism } & Sociodemographic & Gender & .007 & .007 & -.083 & -2.355 & $.019^{*}$ & 5.423 & $.020^{*}$ \\
\hline & & Age & .012 & .005 & -.074 & -2.094 & $.037^{\star *}$ & 4.915 & $.008^{* *}$ \\
\hline & Work & Stressful work & .070 & .070 & -.246 & -6.788 & $.000^{\star * *}$ & 45.737 & $.000^{* * *}$ \\
\hline & & Leisure activities & .089 & .019 & .131 & 3.395 & $.001^{\star \star}$ & 29.811 & $.000^{* * *}$ \\
\hline & & $\begin{array}{l}\text { Years of job } \\
\text { experience }\end{array}$ & .097 & .008 & -.115 & -2.887 & $.004^{\star *}$ & 21.816 & $.000^{* * *}$ \\
\hline & & Workplace & .106 & .009 & .103 & 2.494 & $.013^{\star}$ & 18.051 & $.000^{* * *}$ \\
\hline & $\begin{array}{l}\text { Work-family } \\
\text { interaction }\end{array}$ & $\begin{array}{l}\text { Negative work- } \\
\text { family interaction }\end{array}$ & .383 & .383 & .621 & 22.998 & $.000^{\star * *}$ & 519.571 & $.000^{* * *}$ \\
\hline & & $\begin{array}{l}\text { Positive family- } \\
\text { work interaction }\end{array}$ & .390 & .007 & .085 & 3.132 & $.002^{\star *}$ & 267.423 & $.000^{* * *}$ \\
\hline \multirow{7}{*}{$\begin{array}{l}\text { Compulsive } \\
\text { work }\end{array}$} & Sociodemographic & Age & .018 & .018 & -.136 & -3.882 & $0.000^{* * *}$ & 15.070 & $.000^{* * *}$ \\
\hline & Work & Stressful work & .036 & .036 & -.197 & -4.862 & $0.000^{* * *}$ & 22.298 & $.000^{* * *}$ \\
\hline & & $\begin{array}{l}\text { Years of job } \\
\text { experience }\end{array}$ & .056 & .020 & -.165 & -4.093 & $0.000^{\star * *}$ & 18.230 & $.000^{* * *}$ \\
\hline & & Leisure activities & .067 & .010 & .096 & 2.436 & $0.015^{\star \star}$ & 14.541 & $.000^{* * *}$ \\
\hline & & Workplace & .076 & .009 & .100 & 2.399 & $0.017^{\star \star}$ & 12.431 & $.000^{* * *}$ \\
\hline & $\begin{array}{l}\text { Work-family } \\
\text { interaction }\end{array}$ & $\begin{array}{l}\text { Negative work- } \\
\text { family interaction }\end{array}$ & .225 & .225 & .487 & 15.852 & $.000^{\star * *}$ & 243.580 & $.000^{* * *}$ \\
\hline & & $\begin{array}{l}\text { Positive work- } \\
\text { family interaction }\end{array}$ & .232 & .006 & .080 & 2.593 & $.010^{* *}$ & 125.985 & $.000^{* * *}$ \\
\hline \multirow{5}{*}{$\begin{array}{l}\text { Excessive } \\
\text { work }\end{array}$} & Sociodemographic & Gender & .007 & .007 & -.082 & -2.337 & $.020^{\star}$ & 5.462 & $.020^{*}$ \\
\hline & Work & Stressful work & .079 & .079 & -.267 & -6.905 & $.000^{\star * *}$ & 52.278 & $.000^{* * *}$ \\
\hline & & Leisure activities & .099 & .021 & .144 & 3.729 & $.000^{\star * *}$ & 33.644 & $.000^{* * *}$ \\
\hline & $\begin{array}{l}\text { Work-family } \\
\text { interaction }\end{array}$ & $\begin{array}{l}\text { Negative work- } \\
\text { family interaction }\end{array}$ & .383 & .383 & .621 & 22.951 & $.000^{* * *}$ & 519.271 & $.000^{* * *}$ \\
\hline & & $\begin{array}{l}\text { Positive family- } \\
\text { work interaction }\end{array}$ & .388 & .006 & .075 & 2.767 & $.006^{\star *}$ & 265.528 & $.000^{* * *}$ \\
\hline
\end{tabular}

${ }^{*} p \leq .050 \quad{ }^{* *} p \leq .010 \quad{ }^{* * *} p \leq .001$.

Source: Authors elaboration.

interaction and the positive family-work interaction were highlighted, corroborating national ${ }^{30,43}$ and international studies ${ }^{57}$. Also, authors found higher mean values for the positive influence in both work-family interaction and family-work interaction directions $s^{58-59}$. Furthermore, the negative effects of work within the family have been addressed in several studies ${ }^{15,17}$.

A negative and weak interaction between workaholism and the negative work-family interaction was also found, much in line with other findings ${ }^{22,48}$.

Regarding workaholism and its dimensions, the main predictor found in the present study was the work-family interaction, with a greater negative impact on the negative work-family interaction dimension. This result is in line with the literature, suggesting that the family is one of the variables with higher influence on workaholism $^{15,60-61}$, associated with the most prominent societal changes with women playing an active role in the labour market and also the reshaping of family and professional role-play ${ }^{5,62}$.

Considering occupational variables, only the perception of stress and leisure activities were found to be predictors. However, the impact of stress was found higher and negative compared to leisure activities. These results are in line with the model ${ }^{15}$ and the study $y^{63}$, who identified stress as one of the antecedents of workaholism. Also, some studies point out to other factors, such as job demands, organizational culture, available resources and work overload ${ }^{12,18,61}$. On the other hand, among the sociodemographic variables, 
age and gender were found to be significant predictors. However, gender did not show a significant association with compulsive work, much in line with the other findings ${ }^{64-66}$. Contrarily, a study suggests that male gender constitutes a risk factor ${ }^{60}$.

This study presents as limitations its cross-sectional nature and its online dissemination. However, the study points out some strengths such as the sample size, and insight on the work-family interaction variable in both directions and quality of influence, aiming to explain the workaholism phenomenon in a sample of nurses.

\section{Conclusions}

These study findings confirm the existence of workaholism among nurses, showing moderate values, but higher for compulsive work. Considering the work-family interaction, the negative influence expressed by the work-family interaction direction was highlighted, and it was also found to be the best predictor for workaholism, indicating that the higher the negative work-family interaction, the higher workaholism, compulsive work and excessive work. Regarding other predictor variables, workaholism, compulsive work and excessive work were found to be asso- ciated with nurses showing a lower perception of stress and with younger and female nurses, compared to those who reported engaging in leisure activities.

Considering these findings, further studies should be undertaken to help better understand the phenomenon in nursing professionals, namely by adding new organizational variables and with a longitudinal character. Moreover, it would be of great interest to integrate these themes into the scope of the nursing degree course.

In sum, this study contributes to raise managers' awareness of the importance of work organisation, integrating the family dimension and contributing to the development of programmes to promote health at work. Furthermore, it will likely enhance the work-family-work integration, namely by implementing measures favouring the work-family interaction and enabling the assessment of the impact of the implemented programmes. It is important to notice that work-family balance directive ${ }^{67}$ introduces in Europe, since june 2019, a set of legislative actions designed to promote a less conflict with this major current roles of workers' life. Moreover, with sudden events such as COVID-19 pandemic, nurses are suffered increased demand that can lead to workaholism and difficult an adequate balance between work and family.

\section{Collaborations}

EMN Borges, CAC Sequeira, MP Mosteiro-Díaz contributed to study design and study supervision. EMN Borges contributed to data collection. Elisabete Borges and CML Queirós contributed to data analysis. EMN Borges, CAC Sequeira, CML Queirós and MP Mosteiro-Díaz contributed to manuscript writing, critical revisions of the important intellectual content, final approval of the version to be published. 


\section{Acknowledgments}

The authors would like to thank the Ordem dos Enfermeiros for their collaboration in disseminating this study.

\section{Funding}

This article was supported by National Funds through FCT - Fundação para a Ciência e a Tecnologia ,I.P., within CINTESIS, R\&D Unit (reference UIDB/4255/2020).

\section{References}

1. International Labour Organization (ILO). Decent work and the 2030 agenda for sustainable development. 2017. [cited 2020 Maio 25]. Available from: https:// www.ilo.org/global/topics/sdg-2030/lang--en/index. htm.

2. Eurofound. Agency for the improvement of living and working conditions. Striking a balance: Reconciling work and life in the EU. Luxembourg: Publications Of fice of the European Union. 2018. [cited 2020 Maio 25]. Available from: http://eurofound.link/ef18039. 2020.

3. Eurofound. Agency for the improvement of living and working conditions. Working conditions and workers health. 2019. [cited 2020 Maio 25]. Available from: http://eurofound.link/ef18041.

4. Molino M, Cortese C, Ghislieri C. Unsustainable Working Conditions: The Association of Destructive Leadership, Use of Technology, and Workload with Workaholism and Exhaustion. Sustainability 2019; $11: 446$.

5. Bandeira EL, Ferreira VC, Cabral AC. Conflito trabalho-família: a produção científica internacional e a agenda de pesquisa nacional [Internet]. REAd. Rev Eletronica Admin (Porto Alegre) 2019; 25:49-82.

6. Carver PE, Phillips J. Novel Coronavirus (COVID-19) What You Need to Know [Internet]. Workplace Health Safety 2020; 68:250.

7. Prestia AS. The Moral Obligation of Nurse Leaders: COVID-19. Nurse Leader 2020; 18(4):326-328.

8. Baldonedo M, Mosteiro P, Queirós C, Borges E, Abreu M. Stress no trabalho em enfermeiros: estudo comparativo Espanha/Portugal [Internet]. IJWC 2018; 15:67-80.

9. Bakhamis L, Paul DP, Smith H, Coustasse A. Still an Epidemic. Health Care Manag 2019; 38:3-10.

10. Pérez-Fuentes M, Jurado MM, Martínez, AM, Martínez A M, Linares J G. Burnout and Engagement: Personality Profiles in Nursing Professionals. J Clin Med 2019; 8:286.

11. Di Stefano G, Gaudiino M. Workaholism and work engagement: how are they similar? How are they different? A systematic review and meta-analysis. Eur J Work Organ Psychol 2019; 28:329-347.

12. Hermansyah Riyadi A. Meta-Analysis Study on Correlation of Workloads and Work Stress Among Nurses in Hospital. Res Humanities Social Sci 2019; 6:16-23.

13. Nonnis M, Massidda D, Cuccu S, Massidda D. The Impact of Workaholism on Nurses' Burnout and Disillusion. Open Psychol J 2018; 11:77-88.

14. Schaufeli WB, Shimazu A, Taris TW. Being Driven to Work Excessively Hard. Cross Cult Res 2009; 43:320348.

15. Ng TWH, Sorensen KL, Feldman DC. Dimensions, antecedents, and consequences of workaholism: A conceptual integration and extension. J Organ Behav 2007; 28:111-136.

16. Schaufeli WB, Bakker AB, van der Heijden FMMA et al. Workaholism among medical residents: It is the combination of working excessively and compulsively that counts. Int J Stress Manag 2009; 16: 249-272. 
17. Liang YW, Chu CM. Personality Traits and Personal and Organizational Inducements: Antecedents of Workaholism. Soc Behav Pers. 2009; 37:645-660.

18. Andreassen CS, Pallesen S, Moen BE, Bjorvatn B, Waage S, Schaufeli WB Workaholism and negative work -related incidents among nurses. Ind Health 2018; 56:373-381.

19. Ariapooran S. Sleep problems and depression in Iranian nurses: The predictive role of workaholism. Iran J Nurs Midwifery Res 2019; 24:30.

20. Kwak Y, Kim JS, Han Y, Seo Y. The Effect of Work Addiction on Korean Nurses' Professional Quality of Life. J Addict Nurs 2018; 29:119-127.

21. Midje HH, Nafstad IT, Syse J, Torp S. Workaholism and mental health problems among municipal middle managers in Norway. J Occup Environ Med 2014; 56:1042-1051.

22. Braun AC, Machado WL, Andrade AL, Oliveira MZ. Why work-family conflict can drive your executives away? [Internet]. Rev Psicol 2019; 37:251-278.

23. Hakanen J, Peeters M. How Do Work Engagement, Workaholism, and the Work-to-Family Interface Affect Each Other? A 7-Year Follow-Up Study. J Occup Environ Med 2015; 57:601-609.

24. Torp S, Lysfjord L, Midje HH. Workaholism and work-family conflict among university academics. Higher Educ 2018; 76:1071-1090.

25. Geurts S, Demerouti E. Work/Non-Work Interface: A review of theories and Findings. In: MJ Schabracq, JAM Winnubst, CL Cooper, ed. The Handbook of Work \& Health Psychology. $2^{\text {nd }}$ ed. West Sussex: John Wiley \& Sons, Ltd.; 2003:279-312.

26. Mesmer-Magnus J, Viswesvaran C. Convergence between measures of work- to-family and family-to -work conflict: A meta-analytic examination. J Vocat Behav 2005; 67:215-232.

27. Matias M, Fontaine AM. A conciliação de papeis profissionais e familiares: o mecanismo psicologico de spillover [Internet]. Psic: Teor Pesq 2012; 28:235-243.

28. Silva AR, Silva IS. Conflito trabalho-família: um estudo com motoristas profissionais. Rev Psicol Organ Trab 2015; 16:419-430.

29. Geurts S, Taris T, Kompier MAJ, Dikkers J, Van Hoof MLM, Kinnunen U. Work-family interaction from a work psychological perspective: development and validation of a new questionnaire, the SWING. Work Stress 2005; 19:319-339.

30. Pereira AM, Queirós C, Gonçalves SP, Carlotto MS, Borges E. Burnout e interação trabalho-família em enfermeiros: estudo exploratório com o Survey WorkFamily, Interaction Nijmegen (SWING) [Internet]. RPESM 2014; 11:24-30.

31. Molino M, Cortese CG, Bakker AB, Ghislieri C. Do recovery experiences moderate the relationship between workload and work-family conflict? Career $\mathrm{Dev}$ Int 2015; 20:686-702.

32. Zhou ZE, Meier LL, Spector PE. The spillover effects of coworker, supervisor, and outsider workplace incivility on work-to-family conflict: A weekly diary design. J Organ Behav 2019; 40:1000-1012.
33. Bowen P, Govender R, Edwards P, Cattell, K. Work -related contact, work-family conflict, psychological distress and sleep problems experienced by construction professionals: an integrated explanatory model. Constr Manag Econ 2017; 36:153-174.

34. Schieman S, Young MC. Are communications about work outside regular working hours associated with work-to-family conflict, psychological distress and sleep problems? Work Stress 2013; 27:244-261.

35. Lu Y, Hu XM, Huang XL, Zhuang XD, Guo P, Feng LF, Hu W, Chen L, Zou H, Hao YT. The relationship between job satisfaction, work stress, work-family conflict, and turnover intention among physicians in Guangdong, China: a cross-sectional study. BMJ Open 2017; 7:e014894.

36. Saruan NAM, Yusoff HM, Fauzi MFM. Family responsibilities and involuntary job absenteeism among nurses in teaching hospital. MJPHM 2019; 19:38-46.

37. Feijó MR, Júnior EG, Nascimento JM, Nascimento NB. Work-family Conflict: A Study on the Subject in the Brazilian Context. Pensando Fam 2017; 21:105119.

38. Molino $\mathrm{M}$, Bakker $\mathrm{AB}$, Ghislieri C. The role of workaholism in the job demands resources model. Anxiety Stress Coping 2016; 29:400-414.

39. Zhang Y, ElGhaziri M, Nasuti S, Duffy JF. The Comorbidity of Musculoskeletal Disorders and Depression: Associations with Working Conditions Among Hospital Nurses. Workplace Health Saf 2020; 68(7):346354.

40. Cheng SY, Lin PC, Chang YK, Lin YK, Lee PH, Chen SR. Sleep quality mediates the relationship between work-family conflicts and the self-perceived health status among hospital nurses. J Nurs Manag 2018; 27:381-387.

41. Chen YC, Guo YLL, Lin LC, Lee YJ, Hu PY, Ho JJ, Shiao JSC. Development of the Nurses' Occupational Stressor Scale. Int J Environ Res Public Health 2020; 17:649.

42. Fang YX. Burnout and work-family conflict among nurses during the preparation for reevaluation of a grade a tertiary hospital. Chin. Nurs Res 2017; 4:51-55.

43. Queirós C, Carlotto MS, Kaiseler M, Dias S, Pereira AM. Predictors of burnout among nurses: an interactionist approach. Psicothema 2013; 25:330-335.

44. Namdari S, Nasiri A, Nakhaee S, Taheri, F. Exploring the Effects of Nurses' Family-Work Conflict on Patient Care Quality: A Qualitative Study. Mod Care J 2019; 16:e86130.

45. Leineweber C, Chungkham HS, Westerlund H, Tishelman C, Lindqvist R. Hospital organizational factors influence work-family conflict in registered nurses: Multilevel modeling of a nation-wide cross-sectional survey in Sweden. Int J Nurs Stud 2014; 51:744-751.

46. Gillet N, Morin AJS, Sandrin E, Houle SA. Investigating the combined effects of workaholism and work engagement: A substantive-methodological synergy of variable-centered and person-centered methodologies. J Vocat Behav 2018; 109:54-77.

47. Mahavianpoor A, Mirjafari. The prediction of job burnout based on work addiction and work-family conflict and family conflict-work among nurses. IJHW. 2018; 9:874-877. 
48. Tahir S, Aziz S. Workaholism as Predictor of WorkFamily Conflict and Mental Well-Being: Comparison of Public and Private Sector Employees. PJCSS 2019; 13:419-435.

49. Carlotto MS, Miralles M. Tradução, adaptação e exploração de propriedades psicométricas da Escala de Adição ao Trabalho Dutch Work Addiction Scale (DUWAS). Contextos Clínicos 2010; 3:141-150.

50. Field A. Descobrindo a estatística usando o SPSS, $2^{\mathrm{a}} \mathrm{ed}$. Porto Alegre: Artmed Editora; 2009. p. 688

51. Pestana M, Gageiro J. Análise de dados para ciências sociais: A complementaridade do SPSS. $4^{\text {a }}$ ed. Lisboa: Edições Sílabo; 2005. p. 690

52. Pinheiro LRS, Carlotto MS. Prevalência e preditores da adição ao trabalho em gestores. Rev Psicol 2018; 27:1-11.

53. Vazquez ACS, Freitas CPP, Cyrre A, Hutz CS, Schaufeli WB. Evidências de Validade da Versão Brasileira da Escala de Workaholism (DUWAS-16) e sua versão breve (DUWAS-10). Rev Aval Psicol 2018; 17:69-78.

54. Balducci C, Avanzi L, Consiglio, C, Fraccaroli F, Schaufeli WA. cross-national study on the psycfamily tric quality of the Italian version of the Dutch Work Addiction Scale (DUWAS). Eur J Psychol Assess 2017; 33:422-428.

55. Mir I, Kamal A, Masood S. Translation and Validation of Dutch Workaholism Scale. Pak J Psychol Res 2016; 31:331-346.

56. Nonnis M, Cuccu S, Cortese CG, Massidda D. The Italian version of the Dutch Workaholism Scale (DUWAS): A study on a group of nurses. BPA Appl Psychol Bull 2017; 65:47-57.

57. Romeo M, Berger R, Yepes-Baldó M, Ramos B. Adaptación y validación de la versión española de la "Survey Work-Home Interaction - NijmeGen” (SWING) en países hispanohablantes. An Psicol 2014; 30: 287 293.

58. Moreno-Jimémez B, Sanz-Vergel AI, Rodríguez -Muñoz A, Geurts S. Propiedades psicométricas de la versión española del Cuestionario de Interacción Trabajo-Familia (SWING). Psicothema 2009; 21:331-337.

59. Shimada K, Shimazu A, Geurts SAE, Kawakami N. Reliability and validity of the Japanese version of the Survey Work-Family Interaction - NijmeGen, the SWING (SWING-J). Community Work Fam 2018; 22(3):267-283.

60. Luque AMA. Workaholism: la adicción al trabajo. $L a$ Ciencia en la Calle [internet]. 2017; 1-12. [cited 2020 Maio 25]. Available from: https://pt.slideshare.net/ AnaMAguilera/workaholism-la-adiccin-al-trabajo.

61. Salanova MS, Del Líbano M, Llorens S. La adicción al trabajo. In: Moreno Jiménez B, Hernández EG. Salud laboral: riesgos laborales psicosociales y bienestar laboral. Madrid: Piramide; 2013. p. 241-260.

62. Medeiros TJ, Aguiar J, Barham EJ. Between conflict and balance: reflections on work-family reconciliation. Psicol Argum 2017; 35:45-62.

63. Lichtenstein MB, Malkenes M, Sibbersen C, Hinze C.J. Work addiction is associated with increased stress and reduced quality of life: Validation of the Bergen Work Addiction Scale in Danish. Scand J Psychol 2019; 60:145-151.
64. Andreassen CS, Griffiths MD, Sinha R, Hetland J, Pallesen S. The Relationships between Workaholism and Symptoms of Psychiatric Disorders: A Large-Scale Cross-Sectional Study. PLoS One 2016; 11:e0152978.

65. Dordoni P, Kraus-Hoogeveen S, Van Der Heijden, BIJM, Peters P, Setti I, Fiabane E. Live to Work or Work to Live? An Age-Moderated Mediation Model on the Simultaneous Mechanisms Prompted by Workaholism Among Health care Professionals. Front Psychol 2019; 10:868.

66. Jaworek M, Dyląg A. Workaholism and work engagement: Differences and mutual relationship. Jagiellonian J Manag 2016; 2:275-286.

67. European Parliament \& The Council of The European Union (2019, 20 June). Directive (EU) 2019/1158 [cited 2020 Maio 25]. Available from: http://data.europa.eu/eli/dir/2019/1158/oj.
Article submitted 23/06/2020

Approved 04/07/2021

Final version submitted 06/07/2021

Chief editors: Romeu Gomes, Antônio Augusto Moura da Silva 
